\title{
Antimicrobial activity of Stomoxys calcitrans against Beauveria bassiana sensu lato isolates
}

\author{
Atividade antimicrobiana de Stomoxys calcitrans contra isolados de Beauveria bassiana sensu lato \\ Ana Paula Rodrigues de Moraes ${ }^{1}$; Cristiane Martins Cardoso de Salles²; \\ Vânia Rita Elias Pinheiro Bittencourt ${ }^{3}$; Avelino José Bittencourt ${ }^{4^{*}}$ \\ ${ }^{1}$ Fundação Instituto de Pesca do Estado do Rio de Janeiro, Cordeiro, RJ, Brasil \\ ${ }^{2}$ Departamento de Química, Instituto de Ciências Exatas, Universidade Federal Rural do Rio de Janeiro - UFRRJ, \\ Seropédica, RJ, Brasil \\ ${ }^{3}$ Departamento de Parasitologia Animal, Instituto de Veterinária, Universidade Federal Rural do Rio de Janeiro - UFRRJ, \\ Seropédica, RJ, Brasil. \\ ${ }^{4}$ Departamento de Medicina e Cirurgia Veterinária, Instituto de Veterinária, Universidade Federal Rural do Rio de Janeiro - UFRRJ, \\ Seropédica, RJ, Brasil
}

Received April 17, 2015

Accepted July 20, 2015

\begin{abstract}
This study had the aims of evaluating the antimicrobial characteristics of Stomoxys calcitrans (Diptera: Muscidae) larvae against the fungal isolates CG138, CG228 and ESALQ986 of Beauveria bassiana sensu lato (Balsamo-Crivelli) Vuillemin, 1912 (Hypocreales: Cordycipitaceae). S. calcitrans eggs, larvae and pupae were exposed to these same isolates. Statistical analysis showed that the immature stages of $S$. calcitrans were not susceptible to the fungal isolates used, regardless of the exposure method. Diffusion test on solid culture medium reveled that macerated S. calcitrans larvae exposed to isolate CG138 reduced CG138 fungal development. The analysis of the chromatographic profiles indicated that the macerate or mucus of larvae of the control group and the groups exposed to the isolate CG138 presented different profiles. Reduced development of the isolate CG138 on the larvae cuticle was observed by means of scanning electron microscopy.
\end{abstract}

Keywords: Stomoxys calcitrans, Beauveria bassiana, antimicrobial activity, biological control.

\section{Resumo}

Este estudo teve como objetivos avaliar as características antimicrobianas de larvas de Stomoxys calcitrans (Diptera: Muscidae) contra os isolados CG138, CG228 e ESALQ986 de Beauveria bassiana sensu lato (Balsamo-Crivelli) Vuillemin, 1912 (Hypocreales: Cordycipitaceae). Ovos, larvas e pupas de S. calcitrans foram expostos a estes mesmos isolados. Após análise estatística, foi verificado que os estágios imaturos de $S$. calcitrans não foram susceptíveis aos isolados utilizados, independentemente do método de exposição utilizado. $\mathrm{O}$ teste de difusáo em meio sólido mostrou que quando o isolado CG138 foi exposto a macerado de larvas houve redução do desenvolvimento fúngico. A análise dos perfis cromatográficos mostrou que o macerado ou muco de larvas do grupo controle e dos grupos expostos ao isolado CG138 apresentaram diferenças nos perfis. Um desenvolvimento reduzido do isolado CG138 na cutícula de larvas foi observado pela microscopia eletrônica de varredura.

Palavras-Chave: Stomoxys calcitrans, Beauveria bassiana, atividade antimicrobiana, controle biológico.

\section{Introduction}

Stomoxys calcitrans (Linnaeus, 1758) is an important hematophagous fly that infests Brazilian livestock (GUIMARÁES, 1984), causing annual losses to breeders in this country estimated at US\$335.46 million (GRISI et al., 2014). This fly has been

*Corresponding author: Avelino José Bittencourt. Departamento de Medicina, Instituto de Veterinária e Cirurgia Veterinária, Universidade Federal Rural do Rio de Janeiro - UFRRJ, BR 465 Km 7, CEP 23890-000, Seropédica, RJ, Brasil.e-mail: bittenc@ufrrj.br described parasitizing many species of wild and domesticated animals, including pets, as well as humans (GUIMARÁES, 1984).

Beauveria bassiana sensu lato (Balsamo) Vuillemin (Deuteromycotina: Hyphomycetes) is among the most widely studied entomopathogenic fungi (ALVES, 1998) and has been described parasitizing $S$. calcitrans adults with low prevalence (SKOVGARD \& STEENBERG, 2002). Different isolates have been used to control arthropods that affect livestock (FERNANDES et al., 2006) and 
crops (ALVES, 1998). Other studies have assessed this species' genetic variability and geographic distribution (FERNANDES et al., 2006; FERNANDES et al., 2009), interaction with chemical insecticides (McCOY \& TIGANO-MILANI, 1992), tolerance to stress conditions and performance (FERNANDES et al., 2007), enzymatic activity, production of toxins and action on beneficial arthropods, animals and humans (ZIMMERMANN, 2007).

A good deal of research is currently focused on pest control methods, in line with the principles of integrated pest management (CARLBERG, 1986). However, few studies have examined the use of entomopathogenic fungi for biological control (WATSON et al., 1995; SKOVGARD \& STEENBERG, 2002; MORAES et al., 2008), or the antimicrobial mechanisms of the immature stages of $S$. calcitrans.

Methods such as inhibition zone tests have confirmed that the intestinal extracts of the stable fly $S$. calcitrans present antimicrobial activity (HAMILTON et al., 2002). Urbanek et al. (2012) demonstrated fungistatic activity against entomopathogenic fungi in secretions from Forcipomyia nigra larvae. The most widely used technique for antimicrobial peptide purification and characterization consists of their separation through reversed-phase high performance liquid chromatography (HPLC). HPLC has shown that the antimicrobial peptide identified as stomoxin, which is involved in epithelial immunity mechanisms in the gut of $S$. calcitrans adults, is expressed and secreted exclusively in this fly's foregut. Stomoxin presents a wide spectrum of activities that affect the growth of microorganisms (BOULANGER et al., 2002). Han et al. (1998) found that larvae of Drosophila sp. infected by entomopathogenic fungi produced peptides as a temporary adaptive immunological response. Scanning electron microscopy has been used to prove that certain fungi present inefficient parasitism on arthropods (MELO et al., 2007; URBANEK et al., 2012).

The present study used two exposures methods of immature stages of $S$. calcitrans to fungi (CG138, CG228 and ESALQ986 isolates of B. bassiana s.l.) in the laboratory for evaluated the antimicrobial activity. Macerates and mucus of $S$. calcitrans larvae sensitized with the fungal isolates and macerates and mucus of the larvae of the control group were used to assess the inhibition capacity of the three isolates, through the diffusion test on solid culture medium. Chromatographic profiles were obtained through HPLC to show possible differences between samples. S. calcitrans larvae exposed to the isolate CG138 were examined by means of scanning electron microscopy to investigate fungal adhesion and development on the cuticle and natural openings of the larvae.

\section{Materials and Methods}

\section{Stomoxys calcitrans colony}

The $S$. calcitrans adults were kept in plastic cages $(60 \mathrm{~cm} \mathrm{~L} \times 30 \mathrm{~cm} \mathrm{~W} \times 30 \mathrm{~cm} \mathrm{H})$ and supplied with citrated bovine blood $(0.38 \%)$, while immature stages were maintained using an autoclaved rearing medium composed of a homogenized mixture of sugarcane pulp (66 g), wheat flour (25 g), sodium bicarbonate $(1 \mathrm{~g})$, meat meal $(8 \mathrm{~g})$ and distilled water $(127 \mathrm{ml})$ (CHRISTMAS, 1970; MORAES, 2007).

\section{Beauveria bassiana sensu lato}

The fungal isolates were cultured on potato dextrose agar (PDA, $39 \mathrm{~g} / \mathrm{l}$ ) and $1 \%$ yeast extract (YE) in Petri dishes in the dark at $25^{\circ} \mathrm{C}, 70-80 \% \mathrm{RH}$ for 15 days (FERNANDES et al., 2009).

To prepare the fungal suspensions, isolates were removed from the Petri dishes with a scalpel, suspended and agitated (vortex, 2 min.) in sterile solution (distilled water and $0.01 \%$ Tween in distilled water). A Neubauer chamber was used to count conidia; suspentions were diluted to obtain concentrations of $2 \times 10^{8}, 10^{7}, 10^{6}$ and $10^{5}$ conidia. $\mathrm{ml}^{-1}$ (con.ml ${ }^{-1}$ ). Conidial viability was assessed by inoculating the suspensions in Petri dishes containing PDA and YE and counting the germinated and ungerminated conidia (ALVES, 1998; FERNANDES et al., 2009).

\section{Immature stages of $S$. calcitrans exposed to fungi}

Two fungal exposure methods were used to assess mortality of S. calcitrans immature stages and the percentage adult emergence after larval exposure.

In the first method, 12 groups of $80 \mathrm{~S}$. calcitrans eggs (less than 24 hours-old) were immersed for 2 minutes in suspensions of the three B. bassiana s.l. isolates (CG138, CG228 and ESALQ986) at concentrations of $2 \times 10^{8}, 10^{7}, 10^{6}$ or $10^{5} \mathrm{con} . \mathrm{ml}^{-1}$. The eggs were then transferred to Petri dishes lined with filter paper moistened with $3 \mathrm{ml}$ of sterile distilled water (SENNA-NUNES et al., 2002) and 3 grams of autoclaved rearing medium (MORAES, 2007). The same exposure method was carried out for 12 groups of 30 S. calcitrans larvae, used after 10 days of development. Finally, 8 groups of $32 S$. calcitrans pupae, used 14 days after the eggs had been laid, were immersed for 2 minutes in suspensions of the B. bassiana s.l. isolates CG138 and CG228 at the same fungal concentrations and placed in Petri dishes. All the dishes were sealed with Parafilm ${ }^{\circledast}$, which was perforated with a hypodermic needle $(13 \mathrm{~mm} \times 0.45 \mathrm{~mm})$. The same procedure was used for the control groups, for which the eggs, larvae and pupae were immersed only in a diluent (solution of distilled water and $0.01 \%$ Tween 80) (MORAES et al., 2008).

In the second method, three groups of 80 eggs were immersed for 2 minutes in $0.5 \mathrm{ml}$ of the suspensions of the isolates CG138, CG228 and ESALQ986 at a concentration of $2 \times 10^{8}$ con.ml ${ }^{-1}$. Then, the eggs and suspension were transferred to Petri dishes with the same quantity of rearing medium, but the filter paper was previously moistened with $2.5 \mathrm{ml}$ of the respective fungal suspension. The same method was used for 3 groups of 30 larvae with 10 days of development. The eggs and larvae of the control group were immersed in $0.5 \mathrm{ml}$ of the same diluent and transferred to Petri dishes containing filter paper moistened with $2.5 \mathrm{ml}$ of sterile distilled water and rearing medium. The dishes were sealed and the Parafilm ${ }^{\oplus}$ was perforated as described for the first method (MORAES et al., 2008).

The percentage mortalities of eggs, larvae and pupae were calculated, respectively, 5, 10 and 10 days after the biological assays. The percentage adult emergence was obtained 20 days after exposure of the larvae. The mortality relating to the effect of the fungal isolates was determined by adjusting the natural 
mortality of the controls using Abbott's formula (ABBOTT, 1925). The percentages of mortality and emergence were evaluated using the chi-square test (Bioestat 4.0) with 95\% significance (SAMPAIO, 2002). The assays were carried out twice to obtain more reliable results.

\section{Antimicrobial activity of Stomoxys calcitrans}

\section{Mucus and macerate of Stomoxys calcitrans larvae}

To collect the mucus and macerate of the $S$. calcitrans larvae exposed to the B. bassiana s.l. isolates, groups comprising nine 9-day-old larvae were exposed to the three fungal isolates as in the second method. After three days of incubation, the larvae were washed in sterile distilled water and placed in sterile cryogenic tubes $(1.2 \mathrm{ml})$ for production of mucus (1 hour). The larvae were then removed and $900 \mu \mathrm{l}$ of chilled sterile phosphate buffer solution (PBS) was added (0.1 M; $\mathrm{NaCl} 1.5 \mathrm{M}$; pH 7.4). To obtain the macerate, the larvae were placed in sterile microcentrifuge tubes $(1.5 \mathrm{ml})$, macerated with a conical stick, homogenized with $900 \mu \mathrm{l}$ of the buffer solution and stored in sterile cryogenic tubes $(1.2 \mathrm{ml})$. The macerate and mucus from the larvae of the control groups were obtained in the same way, except that the larvae were only exposed to the diluent (sterile distilled water and $0.01 \%$ Tween). The entire procedure was performed in a laminar flow cabinet. The samples were manipulated on ice and stored in an ultrafreezer $\left(-80^{\circ} \mathrm{C}\right)$.

\section{Diffusion test on solid culture medium}

Ten microliters of fungal suspension of the three isolates (CG138, CG228 and ESALQ986) at a concentration of $1 \times 10^{8}$ con.ml- ${ }^{-1}$ were spread evenly with a sterile swab, in Petri dishes containing PDA (39 g/l), YE (1\%) and chloramphenicol (500 mg/l). Similarly to the method used by Hunt (1986) and Urbanek et al. (2012), two filter paper disks (6 $\mathrm{mm}$ in diameter) were impregnated with chloramphenicol $(500 \mathrm{mg} / \mathrm{l})$, autoclaved $\left(120^{\circ} \mathrm{C}\right.$ for $\left.20 \mathrm{~min}\right)$ and dried in a Pasteur oven $\left(100^{\circ} \mathrm{C}\right)$ and then were immersed in the macerate of larvae that had been previously exposed to the fungal isolates or to the macerate from the control larvae. After the procedure, the disks were placed in dishes containing the fungal suspension. The same procedure was carried out with the mucus samples. These dishes were incubated for three days at $25 \pm 1{ }^{\circ} \mathrm{C}$ and $70-80 \% \mathrm{RH}$. The fungal inhibition zone was ascertained on the second and third days after the start of the experiment.

\section{High performance liquid chromatography (HPLC)}

The mucus and macerate samples from the larvae of the controls and groups exposed to the fungal suspension (CG138 of B. bassiana) were centrifuged (using at refrigerated centrifuge at 10,000 rpm, for $10 \mathrm{~min}$ at $4^{\circ} \mathrm{C}$ ) to obtain the supernatant. The diluent and sodium phosphate buffer were also evaluated. Ten microliters of each sample were applied to a C-18 reversed-phase column (Microssorb, $250 \times 4.6 \mathrm{~mm})$. An isocratic system $(0.1 \%$ trifluoroacetic acid in distilled water) with a flow of $0.6 \mathrm{ml} / \mathrm{min}$ was used. The peaks were detected at $220 \mathrm{~nm}$. For each sample, a maximum period of 30 minutes was needed in order to view all the peaks (BOULANGER et al., 2002).

\section{Scanning electron microscopy}

Groups comprising eight 9-day-old $S$. calcitrans larvae were exposed to a conidial suspension of $B$. bassiana s.l. isolate CG138 at $2 \times 10^{8}$ con. $\mathrm{ml}^{-1}$, as described in the second method of exposure. The fungal viability was appraised as described by Alves (1998). The larvae were removed from the Petri dishes at 0, 2, 15, 24, 48,72 or 96 hours after fungal exposure. They were then fixed in super skipper solution [kerosene (17 pt), glacial acetic acid (11 pt), 95\% ethanol (50 pt), isobutyl alcohol (17 pt) and dioxane (5 pt)] for 30 seconds, washed by means of immersion in Carl's solution [95\% ethanol (28 pt), 45\% formaldehyde (11 pt), glacial acetic acid (4 pt) and $\left.\mathrm{H}_{2} \mathrm{O}(57 \mathrm{pt})\right]$ and maintained in this same solution for 24 hours (GRODOWITZ et al., 1982). Two larvae were used at each of the above mentioned times, to observe whether the fixation process had removed the conidia. For this, the larvae were stained with lactophenol blue cotton, before and after the fixation process, and were viewed under an optical microscope between slides $(40 \times)$ (ALVES, 1998). Six larvae of each group were dehydrated in a graded ethanol series ( 15 minutes in each of $30,50,70,80,85,90$ and $95 \%$ and 3 periods in 100\%), dried in a $\mathrm{CO}_{2}$ critical-point drier and then covered with gold particles (10 milliamperes/90 seconds). Electron micrographs were produced using a JEOL JSM-JEM 1011 scanning electron microscope, with the aim of viewing the conidia, fixation and fungal penetration structures (GRODOWITZ et al., 1982; DEDAVID et al., 2007).

Untreated larvae with or without sonication were compared with larvae that had been exposed to fungus. The larvae were washed in sterile distilled water and sonicated for 3 periods of 30 seconds at $20 \mathrm{kHz}$ (Ultrasonic cell disruptor - Unique R2D091109) in sterile phosphate buffer solution (PBS) $(0.1 \mathrm{M} ; \mathrm{NaCl} 1.5 \mathrm{M}$; $\mathrm{pH} 7.4)$ at $4{ }^{\circ} \mathrm{C}$. Scanning electron microscopy was performed, following the same steps as for the treated larvae.

\section{Results}

\section{Immature stages of S. calcitrans exposed to fungi}

The mortality rates in the treated groups were similar to those of the control groups, for both egg exposure methods (Tables 1 and 2). In some cases, such as the isolate CG138 in the first exposure method, lower percentage mortality was observed for the treated groups in comparison with the control, irrespective of the fungal concentration used (Table 1). The same result was observed in the second exposure method, when the eggs were exposed to the three isolates at a concentration of $2 \times 10^{8}$ con. $\mathrm{ml}^{-1}$.

In the second exposure method, when the eggs and larvae remained in contact with the fungal isolates $\left(2 \times 10^{8}\right.$ con. $\left.\mathrm{ml}^{-1}\right)$ until the end of the experiment, the larvae ingested conidia (Figure 1a), but they did not present behavioral changes, mummification or fungal proliferation on the cuticle or through natural openings. 
Table 1. Mortality of immature stages of Stomoxys calcitrans immersed in aqueous suspensions of three isolates of Beauveria bassiana s.l. using the first method of exposure.

\begin{tabular}{|c|c|c|c|c|c|c|c|}
\hline & & \multicolumn{3}{|c|}{ First Assay } & \multicolumn{3}{|c|}{ Second Assay } \\
\hline \multirow{2}{*}{\multicolumn{2}{|c|}{ Isolates/Concentrations }} & Eggs* & Larvae* & Pupae* & Eggs* & Larvae* & Pupae* \\
\hline & & & & & & & \\
\hline \multicolumn{2}{|c|}{ Control } & 0 & 0 & 0 & 0 & 0 & 0 \\
\hline \multirow[t]{4}{*}{ CG 138} & $2 \times 5^{5}$ con. $\mathrm{ml}^{-1}$ & -28.2 & 0 & 11.1 & $-18,5$ & 12.0 & 4.0 \\
\hline & $2 \times 5^{6}$ con. $\mathrm{ml}^{-1}$ & -5.3 & 4.5 & 25.9 & 0 & 31.0 & -3.9 \\
\hline & $2 \times 5^{7}$ con. $\mathrm{ml}^{-1}$ & -14.2 & 18.1 & -7.4 & 3.7 & 32.0 & 0 \\
\hline & $2 \times 5^{8}$ con. $\mathrm{ml}^{-1}$ & -3.6 & 4.5 & 11.1 & 7.4 & 28.0 & 4.0 \\
\hline \multirow[t]{4}{*}{ CG 228} & $2 \times 5^{5}$ con. $\mathrm{ml}^{-1}$ & 10.7 & -4.5 & 3.7 & 7.4 & 0 & 20.0 \\
\hline & $2 \times 5^{6}$ con $\cdot \mathrm{ml}^{-1}$ & -8.9 & -27.2 & 0 & 9.2 & -12.0 & 12.0 \\
\hline & $2 \times 5^{7}$ con. $\mathrm{ml}^{-1}$ & 7.1 & -13.6 & 3.7 & -33.3 & 8.0 & -8.0 \\
\hline & $2 \times 5^{8}$ con. $\mathrm{ml}^{-1}$ & 8.9 & 4.5 & 11.1 & 0 & 20.0 & -11.9 \\
\hline \multirow[t]{4}{*}{ ESALQ 986} & $2 \times 5^{5}$ con. $\mathrm{ml}^{-1}$ & -14.9 & -3.6 & & 17.6 & 6.7 & \\
\hline & $2 \times 5^{6}$ con. $\mathrm{ml}^{-1}$ & 8.9 & -3.6 & - & 7.3 & 3.3 & \\
\hline & $2 \times 5^{7}$ con. $\mathrm{ml}^{-1}$ & 6.0 & 7.1 & & -4.4 & 13.3 & \\
\hline & $2 \times 5^{8}$ con. $\mathrm{ml}^{-1}$ & 1.5 & 7.1 & & 16.2 & 13.3 & - \\
\hline
\end{tabular}

$\mathrm{CM}=$ Corrected mortality by Abbot's formula. $-=$ Not evaluated. ${ }^{*}=$ No statistical difference between the mortality percentages in the treated groups and control group in each immature stage of Stomoxys calcitrans.

Table 2. Mortality of immature stages of Stomoxys calcitrans immersed and maintained in aqueous suspensions of three isolates of Beauveria bassiana s.l. using the second method of exposure.

\begin{tabular}{|c|c|c|c|c|c|}
\hline & & \multicolumn{2}{|c|}{ First Assay } & \multicolumn{2}{|c|}{ Second Assay } \\
\hline \multicolumn{2}{|c|}{ Isolates/Concentrations } & Eggs* & Larvae* & Eggs* & Larvae* \\
\hline \multirow{2}{*}{\multicolumn{2}{|c|}{ Control }} & & & & \\
\hline & & 0 & 0 & 0 & 0 \\
\hline CG 138 & $2 \times 5^{8}$ con. $\mathrm{ml}^{-1}$ & -16.3 & 0 & -21.8 & -12.5 \\
\hline CG 228 & $2 \times 5^{8}$ con $\cdot \mathrm{ml}^{-1}$ & -5.4 & -11.5 & -5.4 & -16.7 \\
\hline ESALQ 986 & $2 \times 5^{8}$ con. $\mathrm{ml}^{-1}$ & -5.4 & -7.7 & 0 & -16.7 \\
\hline
\end{tabular}

$\mathrm{CM}=$ Corrected mortality by Abbot's formula. ${ }^{*}=$ No statistical difference between the mortality percentages in the treated groups and control group in each immature stage of Stomoxys calcitrans.
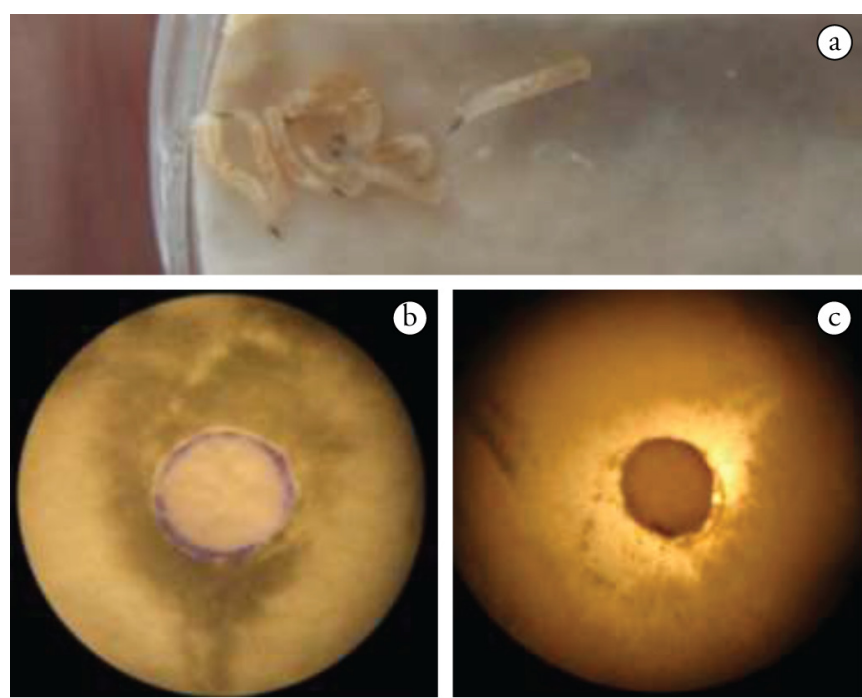

Figure 1. (a) Stomoxys calcitrans larvae ingesting conidia of Beauveria bassiana s.l. (b) and (c) Petri dish in which an inhibition zone of B. bassiana s.l. isolate CG138 was observed by using a macerate from larvae previously sensitized by the same fungus.
Fly emergence rates from the $S$. calcitrans larvae exposed to the two fungal exposure methods were not affected at the concentrations tested (Table 3). The three fungal isolates did not cause any deleterious effect or have any delayed action on the larvae, in either of the methods used.

\section{Antimicrobial activity of Stomoxys calcitrans}

\section{Diffusion test on solid culture medium}

The macerate and mucus from larvae of the control group did not cause the formation of an inhibition zone for the three B. bassiana s.l. isolates utilized (CG138, CG228 and CG986). However, the macerate of larvae previously sensitized with the isolate CG138 reduced the fungal development, leading to formation of an inhibition zone (Figures 1b, c). This was not observed with the other two isolates, where there was good fungal development around the disks moistened with mucus or macerate of larvae that had been exposed to those isolates. Moreover, no inhibition zone 
was observed when the isolate CG138 was challenged with mucus from larvae previously exposed to that isolate.

\section{High performance liquid chromatography (HPLC)}

Alterations to the chromatographic profiles of the macerate and mucus of $S$. calcitrans larvae were observed after exposure to B. bassiana isolate CG138, thereby suggesting that the larvae had an active response against fungal infection (Figures $2 \mathrm{a}-\mathrm{e}$ ). New peaks in the chromatographic patterns of $S$. calcitrans macerate were seen to have appeared, in comparison with the control group. However, the peaks observed in the chromatographic pattern of the mucus of the control group did not remain after larval exposure to the fungus, thereby indicating, respectively, production and mobilization of molecules such as antimicrobial peptide defense molecules.

Table 3. Fly emergence from Stomoxys calcitrans larvae exposed to aqueous suspensions of three isolates of Beauveria bassiana s.l. using the first and the second method of exposure.

\begin{tabular}{|c|c|c|c|c|}
\hline \multirow{2}{*}{ Larval Exposure Method } & \multirow{2}{*}{ Isolate } & \multirow{2}{*}{ Concentrations } & \multicolumn{2}{|c|}{ Emergence } \\
\hline & & & First Assay & Second Assay \\
\hline \multirow[t]{15}{*}{ First* } & CG 138 & Control & 63.3 & 60.0 \\
\hline & & $2 \times 5^{5}$ con. $\mathrm{ml}^{-1}$ & 46.6 & 53.3 \\
\hline & & $2 \times 5^{6}$ con $\cdot \mathrm{ml}^{-1}$ & 56.6 & 36.6 \\
\hline & & $2 \times 5^{7}$ con. $\mathrm{ml}^{-1}$ & 46.6 & 43.3 \\
\hline & & $2 \times 5^{8}$ con. $\mathrm{ml}^{-1}$ & 63.3 & 43.3 \\
\hline & CG 228 & Control & 63.3 & 60.0 \\
\hline & & $2 \times 5^{5}$ con $\cdot \mathrm{ml}^{-1}$ & 66.6 & 66.6 \\
\hline & & $2 \times 5^{6}$ con. $\mathrm{ml}^{-1}$ & 63.3 & 73.3 \\
\hline & & $2 \times 5^{7}$ con $\cdot \mathrm{ml}^{-1}$ & 63.3 & 60.0 \\
\hline & & $2 \times 5^{8}$ con. $\mathrm{ml}^{-1}$ & 60.0 & 53.3 \\
\hline & ESALQ 986 & Control & 80.0 & 90.0 \\
\hline & & $2 \times 5^{5}$ con. $\mathrm{ml}^{-1}$ & 90.0 & 86.6 \\
\hline & & $2 \times 5^{6}$ con. $\mathrm{ml}^{-1}$ & 90.0 & 73.3 \\
\hline & & $2 \times 5^{7}$ con. $\mathrm{ml}^{-1}$ & 83.3 & 73.3 \\
\hline & & $2 \times 5^{8}$ con $\cdot \mathrm{ml}^{-1}$ & 86.6 & 86.6 \\
\hline \multirow[t]{4}{*}{ Second* } & $\mathrm{C}$ & Control & 76.6 & 80.0 \\
\hline & CG 138 & $2 \times 5^{8}$ con. $\mathrm{ml}^{-1}$ & 83.3 & 76.6 \\
\hline & CG 228 & $2 \times 5^{8}$ con $\cdot \mathrm{ml}^{-1}$ & 86.6 & 86.6 \\
\hline & ESALQ 986 & $2 \times 5^{8}$ con. $\mathrm{ml}^{-1}$ & 86.6 & 86.6 \\
\hline
\end{tabular}

$*^{*}=$ No statistical difference between the emergence percentages in the treated groups and control group of Stomoxys calcitrans.

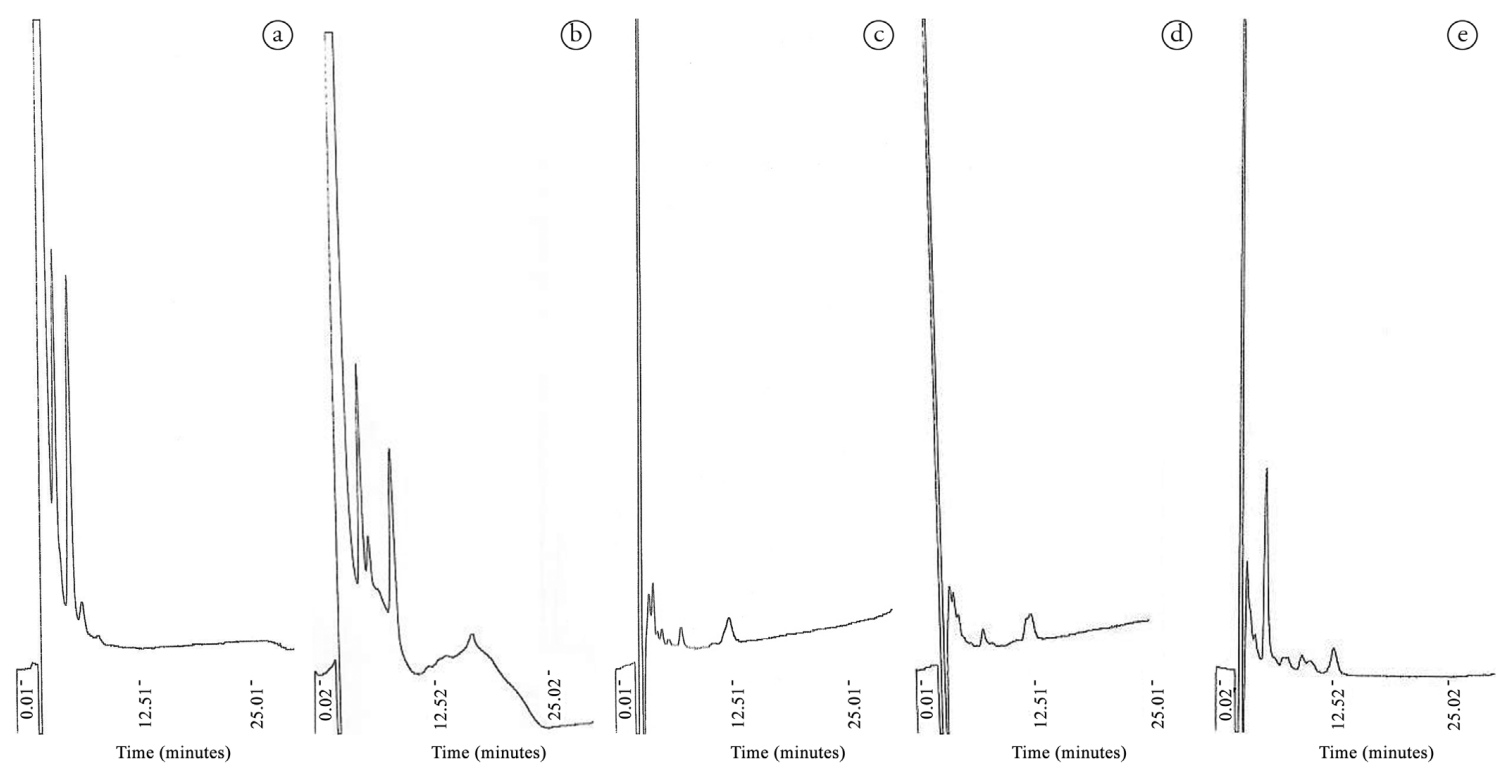

Figure 2. Chromatographic profile (HPLC) of (a) macerate of Stomoxys calcitrans larvae from control group. (b) macerate of S. calcitrans larvae sensitized with the isolate CG138 of Beauveria bassiana. (c) mucus from S. calcitrans larvae of the control group. (d) mucus from S. calcitrans larvae sensitized with the isolate CG138 of B. bassiana and (e) isolate CG138 of B. bassiana. 


\section{Scanning electron microscopy}

The larvae were healthy and presented midgut content (consisting of rearing medium and conidia) when they were fixed with super skipper and Carl's solution (Figure 1a). These solutions did not remove conidia from the body surface of the larvae, as could be seen through optical microscopy.

No germinated conidia were observed in the natural orifices. Structures similar to germ tubes (Figure 3a), enzymatic action (Figure 3b) and appressoria were seen 24, 48, 72 and 96 hours after fungal exposure, but the colonization process was not homogenous. More than one germ tube per conidium was observed (Figure 3c) and some were very elongated, possessing appressorium (Figure 3d). Reduced hyphal development was observed on the body surface of $S$. calcitrans larvae, mainly after 72 and 96 hours.

\section{Discussion}

The results from this study demonstrated that the immature stages of $S$. calcitrans were tolerant to the isolates CG138 and CG228 of B. bassiana s.l. and the low mortality found with the isolate ESALQ986 confirmed what was observed with those isolates. Although this is considered to be an isolate that yields high pathogenicity among arthropods (FERNANDES et al., 2007), it was unable to cause satisfactory mortality rates. In a study on controlling the fly population that develops in bird droppings, Carlberg (1986) reported that S. calcitrans and Fannia canicularis flies were less susceptible to Bacillus thuringiensis than Musca domestica was. The tolerance of the immature stages of $S$. calcitrans to the B. bassiana s.l. isolates observed in the present study demonstrated that natural differences exist among fly species regarding their tolerance to infection by microorganisms. For this reason,
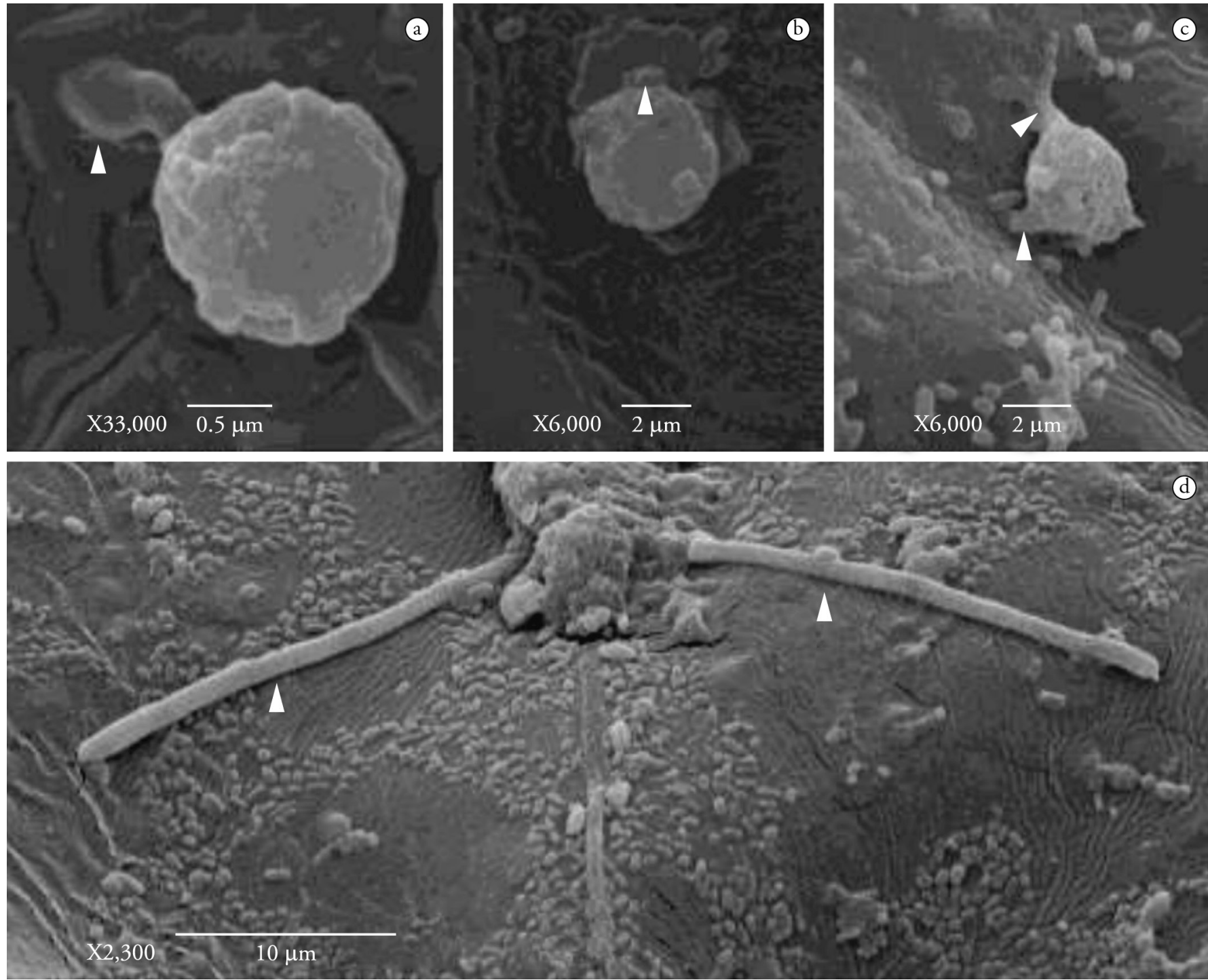

Figure 3. Scanning electron microscopy of Stomoxys calcitrans larvae exposed to Beauveria bassiana s.l. isolate CG138: (a and b) Germ tube and integument penetration (24 hours after fungal exposure) (arrow). (c) Development of more than one germ tube in one conidium (48 hours after fungal exposure) (arrows). (d) Development of more than one germ tube in one conidium (96 hours after fungal exposure) (arrows). 
Watson et al. (1995) suggested that new control agents and the evolutionary mechanisms of these insects should be investigated, in order to develop effective biological control methods.

We used eggs and larvae in the second method because they are considered to be more susceptible to environmental conditions and to parasites and predators, in comparison with pupae (NEVES \& FARIA, 1988). The aim of this method was to promote high fungal infestation, but no significant mortality was observed in comparison with the control groups. Instead, the percentage mortality of the eggs and larvae exposed to the isolates was actually lower. It should be pointed out that the high infestation of this method would not be found in a natural environment or in cases of fungal application in places where the immature stages of $S$. calcitrans develop, which should cause high mortality. This method was used to ascertain whether the first exposure method was influencing the results, mainly because of the use of larvae in the tests, because the intense movement and mucus production might favor removal of the conidia from the surface. Immersion was also utilized to promote intense contact and favor ingestion of the conidia.

The results from the second egg exposure method differed from those reported by Moraes et al. (2008), using Metarhizium anisopliae with a similar exposure method. They found $100 \%$ non-viability of eggs exposed to concentrations of $2 \times 10^{8}$ and $10^{7}$ con.ml- ${ }^{-1}$. The fact that $M$. anisopliae caused high mortality is suggested to be related to the presence of certain enzymes produced by this fungus (GABRIEL, 1968; ALVES, 1998); another possibility could be the time of infection that occurred faster for $M$. anisopliae than for $B$. bassiana s.l. as observed when subterranean termite were exposed (MOINO et al., 2002).

Unlike the results obtained using the eggs, the mortality rates of the larvae and pupae were similar to those found by Moraes et al. (2008), because no significant difference was observed when $S$. calcitrans larvae and pupae were treated with conidial suspensions of $M$. anisopliae. According to Watson et al. (1995), S. calcitrans may have developed mechanisms to tolerate the presence and parasitism of certain microorganisms, possibly related to the highly contaminated environment in which its immature stages develop.

Another interesting observation was the absence of conidial non-viability of the three $B$. bassiana s.l. isolates, because $100 \%$ germination was obtained upon re-isolation of the suspensions used, along with good development of the fungal isolates in the Petri dishes with the immature stages. Fungal colonization of the rearing medium contributed towards development in a medium that was more favorable to the immature stages, which may have been due to the degradation of organic matter or to the availability of the microorganisms themselves as a food source (SCHMIDTMANN \& MARTIN, 1992; PEROTTI et al., 2001; ROMERO et al., 2006). This can be confirmed by the higher mortality rates (Tables 1 and 2) and lower emergence rates (Table 3) observed in the majority of the control groups in the experiments, using both exposure methods. Further confirmation is provided by the good morphological appearance of the immature stages and the intense ingestion of conidia and fungal content in the gut of the larvae (Figure 1a), without causing mobility or behavioral changes or pupal malformation, in contrast to the observations of
Moraes (2007). That author described liquefied pre-emerged larvae, larval paralysis, mummification and pupal malformation when S. calcitrans eggs and larvae were exposed to high concentrations of M. anisopliae (MORAES, 2007). Moreover, in the present study, no behavioral change were noted among the flies that emerged from the pupae treated with fungal suspensions or in either of the two larval exposure methods, unlike what was reported by Alves (1998), who described infected insects suffering from lack of coordination, paralysis or fungal growth in orifices or more fragile sites of the cuticle.

The test on solid culture medium, through formation of the inhibition zone, showed whether the macerate or mucus of the larvae had an inhibitory effect on the three $B$. bassiana s.l. isolates and whether this response was related to the previous exposure of the larvae. The fungal growth observed around the disks moistened with the macerate or mucus from larvae of the control groups suggests that the antimicrobial mechanisms were not previously active to fend off a fungal infection (SILVA, 2002).

The formation of a fungal inhibition zone on disks impregnated with the macerate from larvae sensitized with the isolates CG228 or ESALQ986 may be related to the conditions needed for fungal germination on the solid medium used, in which the ideal nutrient, temperature and humidity conditions are provided for development. These factors may have overcome the inhibitory capacity of the macerate and the mucus from the larvae previously sensitized to these isolates, or the minimum concentration of macerate or mucus necessary to impede fungal development may not have been reached. According to Hunt (1986), the caprylic acid present in Dendroctonus ponderosae and Hyphantria. cunea can inhibit the development of $B$. bassiana s.l. Furthermore, according to that author, the low concentration found in $D$. ponderosae was insufficient to cause fungal inhibition and form an inhibition zone, while that of $H$. cunea showed moderate inhibition under the experimental conditions used. Urbanek et al. (2012) reported on antimicrobial assays performed with mixtures of fatty and pyroglutamic acids. Interestingly, B. bassiana strain Dv-107 was more susceptible to mixtures than B. bassiana strain Tve-N39.

The different chromatographic profiles found for the control group and for the infected larvae demonstrated that the larvae responded to the fungal infection. In general, the observation of new chromatographic peaks in the macerate and mucus, not associated with the peaks of the fungal isolates, suggests that antifungal activity fighting the infection was present. According to Dangl \& Jones (2001), peptides are considered to be primitive elements of the immune response of living beings, and the routes for induction are relatively well conserved in insects. HPLC has shown that the peptide identified as stomoxin is expressed and secreted exclusively in the stable fly's foregut and presents a wide spectrum of activities that affect the growth of microorganisms (BOULANGER et al., 2002). Urbanek et al. (2012) showed that the $F$. nigra secretion contained 12 free fatty acids and that the most effective acids against bacterial and entomopathogenic fungal growth were pelargonic (9:0), capric (10:0) and palmitoleic (16:1).

The colony-forming process of the isolate CG138 (Figures 3a-d) that was observed through scanning electron microscopy was not enough to kill S. calcitrans larvae, since there was no diffuse colonization on the larval integument even with $100 \%$ germination 
on PDA medium. Garcia et al. (2005) reported that $M$. anisopliae s.l. conidia took 18 hours post-infection to germinate on the cuticle of Rhipicephalus sanguineus, and thus established that a period of 48 to 72 hours was required for colonization to be disseminated. Urbanek et al. (2012) suggested that the secretion of $F$. nigra larvae serves as a physical barrier against various possibly pathogenic microorganisms.

Scanning electron microscopy demonstrated that conidia on the larval surface would be affected by a defense mechanism of mucus or integument, which would delay fungal development, similar to what was described for Bradysia hygida larvae with bacteria and yeast (CANDIDO-SILVA et al., 2007), for S. calcitrans adults with bacteria (BOULANGER et al., 2002) and for $F$. nigra larval secretions (URBANEK et al., 2012).

According to Hunt et al. (1984), the development of more than one germ tube in one conidium (Figures 3c, d) is related to the excess amount of nutrients required to maintain larval viability in the current experiment. These nutrients contributed to the development of errant-type hyphae, which delayed the parasitism on the integument.

The fungal inhibition in the diffusion test on solid culture medium caused by the macerate of larvae previously exposed to the isolate CG138, in association with the five retention times observed in the chromatographic profile of the same macerate (Figure 2a) and the results from the scanning electron microscopy, indicates that an antimicrobial response was triggered against the fungal infection, as also noted in studies on entomopathogenic fungi by Munks et al. (2001), using adult forms of S. calcitrans, and by Han et al. (1998), investigating Drosophila sp. larvae. According to Gillespie et al. (2000), the fatty acids of insects have a profound effect on fungal spore germination: they are toxic and fungistatic.

These results obtained from HPLC are preliminary; however, these could indicate that similar peptides or molecules with protective characteristics are produced after exposure to the fungus. More studies are needed to elucidate these molecules and their participation in S. calcitrans protection against external agents, in order to assess the existence of factors relating to the antimicrobial activity observed with immature stages of $S$. calcitrans in fungal exposure tests. In addition, the unsatisfactory results regarding mortality and adult emergence that were reported in the different exposure bioassays were related to the ability of the stable fly's immature stages to restrain the entomopathogenic action of B. bassiana s.l. The difficulty in specifying the substances involved in this response lies in the absence of studies reporting on mucus production by larvae of this species and on its composition and protective activity, since the few studies in the literature cover adult forms of the fly (BOULANGER et al., 2002).

Daffre et al. (2001) reported that studies aiming towards finding natural or synthetic substances with antimicrobial activity and alternative mechanisms not used by conventional antibiotics should be conducted. Several researchers have also mentioned the importance of researching, purifying and chemically, biologically and structurally characterizing efficient new antimicrobial substances that can be used against infections (DAFFRE et al., 2001).

\section{Acknowledgements}

This research was supported by grants from FAPERJ (Fundação Carlos Chagas Filho de Amparo à Pesquisa do Estado do Rio de Janeiro) and PhD scholarships from the CAPES (Coordenação de Aperfeiçoamento de Pessoal de Nível Superior, Brazil). Vania Rita Elias Pinheiro Bittencourt is CNPq researcher (Conselho Nacional de Pesquisa e Desenvolvimento Tecnológico, Brazil).

\section{References}

Abbott WS. A method of computing the effectiveness of an insecticide. J Econ Entomol 1925; 18(2): 265-267. http://dx.doi.org/10.1093/ jee/18.2.265a.

Alves SB. Controle Microbiano de Insetos. Piracicaba: FEALQ; 1998.

Boulanger N, Munks RJL, Hamilton JV, Vovelle F, Brun R, Lehane MJ, et al. Epithelial innate immunity. A novel antimicrobial peptide with antiparasitic activity in the blood-sucking insect Stomoxys calcitrans. J Biol Chem 2002; 277(51): 49921-49926. http://dx.doi.org/10.1074/ jbc.M206296200. PMid:12372834.

Candido-Silva JA, Zanarotti GM, Gallina AP, Almeida JC. Developmental regulation of BhSGAMP-1, a gene encoding an antimicrobial peptide in the salivary glands of Bradysia hygida (Diptera, Sciaridae). Genesis 2007; 45(10): 630-638. http://dx.doi.org/10.1002/dvg.20337. PMid:17941045.

Carlberg G. Bacillus thuringiensis and microbial control of flies. MIRCEN J 1986; 2(2): 267-274. http://dx.doi.org/10.1007/BF00933492.

Christmas PE. Laboratory rearing of the biting fly Stomoxys calcitrans (Diptera: Muscidae). NZ Entomol 1970; 4(4): 45-49. http://dx.doi.org /10.1080/00779962.1970.9723073.

Daffre S, Miranda A, Miranda MTM, Bulet P, Silva PI Jr, Machado A, et al. Peptídeos Antibióticos. Peptídeos antibióticos produzidos por aracnídeos. Biotecnolog Cienc Desenvolv 2001; 23: 48-55.

Dangl JL, Jones JDG. Plant pathogens and integrated defence responses to infection. Nature 2001; 411(6839): 826-833. http://dx.doi. org/10.1038/35081161. PMid:11459065.

Dedavid BA, Gomes CI, Machado G. Microscopia eletrônica de varredura. Aplicaçôes e preparação de amostras: materiais poliméricos, metálicos e semicondutores. Porto Alegre: EDIPUCRS; 2007.

Fernandes EKK, Costa GL, Moraes AML, Zahner V, Bittencourt VREP. Study on morphology, pathogenicity, and genetic variability of Beauveria bassiana isolates obtained from Boophilus microplus tick. Parasitol Res 2006; 98(4): 324-332. http://dx.doi.org/10.1007/s00436-005-0058-y. PMid:16374618.

Fernandes EKK, Moraes AML, Pacheco RS, Rangel DEN, Miller MP, Bittencourt VREP, et al. Genetic diversity among Brazilian isolates of Beauveria bassiana: comparisons with non-Brazilian isolates and other Beauveria species. J Appl Microbiol 2009; 107(3): 760-774. http://dx.doi. org/10.1111/j.1365-2672.2009.04258.x. PMid:19486413.

Fernandes EKK, Rangel DEN, Moraes AML, Bittencourt VREP, Roberts DW. Variability in tolerance to UV-B radiation among Beauveria spp. isolates. J Invertebr Pathol 2007; 96(3): 237-243. http://dx.doi. org/10.1016/j.jip.2007.05.007. PMid:17610892.

Gabriel BP. Enzymatic activities of some entomophthorous fungi. $J$ Invertebr Pathol 1968; 11(1): 70-81. http://dx.doi.org/10.1016/00222011(68)90055-4. PMid:5649245. 
Garcia MV, Monteiro AC, Szabó MJ, Prette N, Bechara GH. Mechanism of infection and colonization of Rhipicephalus sanguineus eggs by Metarhizium anisopliae as revealed by scanning eletron microscopy and histopathology. Braz J Microbiol 2005; 36(4): 368-372. http://dx.doi. org/10.1590/S1517-83822005000400012.

Gillespie JP, Bailey AM, Cobb B, Vilcinskas A. Fungi as elicitors of insect immune responses. Arch Insect Biochem Physiol 2000; 44(2): 49-68. http://dx.doi.org/10.1002/1520-6327(200006)44:2<49::AIDARCH1>3.0.CO;2-F. PMid:10861866.

Grisi L, Leite RC, Martins JR, Barros ATM, Andreotti R, Cançado PHD, et al. Reassessment of the potential economic impact of cattle parasites in Brazil. Rev Bras Parasitol Vet 2014; 23(2): 150-156. http:// dx.doi.org/10.1590/S1984-29612014042. PMid:25054492.

Grodowitz MJ, Krchma J, Broce AB. A method for preparing soft bodied larval diptera for scanning electron microscopy. J Kans Entomol Soc 1982; 55(4): 751-753.

Guimarães JH. Mosca dos estábulos: uma importante praga do gado. Agroq. Ciba - Geigy 1984; (23):10-14.

Hamilton JV, Munks RJL, Lehane SM, Lehane MJ. Association of midgut defensin with a novel serine protease in the blood-sucking fly Stomoxys calcitrans. Insect Mol Biol 2002; 11(3): 197-205. http://dx.doi. org/10.1046/j.1365-2583.2002.00325.x. PMid:12000638.

Han ZS, Enslen H, Hu X, Meng X, Wu IH, Barrett T, et al. A conserved p38 mitogen-activated protein kinase pathway regulates Drosophila immunity gene expression. Mol Cell Biol 1998; 18(6): 3527-3539. PMid:9584193.

Hunt DWA. Absence of fatty acid germination inhibitors for conidia of Beauveria bassiana on the integument of the Bark Beetle Dendroctonus ponderosae (Coleoptera: Scolytidae). Can Entomol 1986; 118(8): 837-838. http://dx.doi.org/10.4039/Ent118837-8.

Hunt DWA, Borden JH, Rahe JE, Whitney HS. Nutrient-mediated germination of Beauveria bassiana conidia on the integument of the Bark Beetle Dendroctonus ponderosae (Coleoptera: Scolytidae). I Invertebr Pathol 1984; 44(3): 304-314. http://dx.doi.org/10.1016/0022-2011(84)90028-4.

McCoy CW, Tigano-Milani MS. Use of entomopathogenic fungi in biological control: a world view. Pesquisa Agropecu Bras 1992; 27: 87-93.

Melo DR, Cruz GB, Reis RCS, Bittencourt VREP. Desenvolvimento dos fungos Metarhizium anisopliae (Metschnikoff, 1879) Sorokin, 1883 e Beauveria bassiana (Balsamo) Vuillemin, 1912 sobre Ctenocephalides felis felis (Bouché, 1835). Rev Bras Parasitol Vet 2007; 16(3): 166-170. http:// dx.doi.org/10.1590/S1984-29612007000300011. PMid:18078609.

Moino A Jr, Alves SB, Lopes RB, Neves PMOJ, Pereira RM, Vieira AS. External development of the entomopathogenic fungi Beauveria bassiana and Metarhizium anisopliae in the subterranean termite Heterotermes tenuis. Sci Agric 2002; 59(2): 267-273. http://dx.doi.org/10.1590/ S0103-90162002000200010.

Moraes APR. Stomoxys calcitrans: estabelecimento de colônia e efeito de Metarhizium anisopliae sobre seus estágios imaturos [Masters dissertation]. Rio de Janeiro: Universidade Federal Rural do Rio de Janeiro; 2007.
Moraes APR, Angelo IC, Fernandes EKK, Bittencourt VREP, Bittencourt AJ. Virulence of Metarhizium anisopliae to eggs and immature stages of Stomoxys calcitrans. Ann N Y Acad Sci 2008; 1149(1): 384-387. http:// dx.doi.org/10.1196/annals.1428.008. PMid:19120256.

Munks RJL, Hamilton JV, Lehane SM, Lehane MJ. Regulation of midgut defensin production in the blood-sucking insect Stomoxys calcitrans. Insect Mol Biol 2001; 10(6): 561-571. http://dx.doi.org/10.1046/j.09621075.2001.00296.x. PMid:11903625.

Neves DP, Faria AC. Profundidade de empupação de Stomoxys calcitrans (Diptera, Muscidae) e presença de microhimenópteros parasitóides nas pupas. Rev Bras Biol 1988; 48(4): 911-913.

Perotti MA, Lysyk TJ, Kalischuk-Tymensen LD, Yanke LJ, Selinger LB. Growth and survival of immature Heamatobia irritans (Diptera; Muscidae) is influenced by bacterial isolated from cattle manure and conspecific larvae. J Med Entomol 2001; 38(2): 180-187. http://dx.doi. org/10.1603/0022-2585-38.2.180. PMid:11296820.

Romero A, Broce A, Zurek L. Role of bacteria in the oviposition behaviour and larval development of stable flies. Med Vet Entomol 2006; 20(1): 115-121. http://dx.doi.org/10.1111/j.1365-2915.2006.00602.x. PMid:16608496.

Sampaio IBM. Estatística aplicada à experimentação animal. Belo Horizonte: Fundaçáo de Ensino e Pesquisa em Medicina Veterinária e Zootecnia; 2002.

Schmidtmann ET, Martin PAW. Relationship between selected bacteria and the growth of immature house flies, Musca domestica, in an axenic test system. J Med Entomol 1992; 29(2): 232-235. http://dx.doi.org/10.1093/ jmedent/29.2.232. PMid:1495035.

Senna-Nunes M, Costa GL, Bittencourt VREP, Souza EJ. Avaliação in vitro dos fungos Aspergillus flavus e Penicillium corylophilum em larvas de Musca domestica (Diptera: Muscidae). Parasitol Latinoam 2002; 57(1-2): 134-140.

Silva CCA. Aspectos do sistema imunológico dos insetos. Novos discernimentos e perspectivas. Biotecnolog Cienc Desenvolv 2002; 24: 68-72.

Skovgard H, Steenberg T. Activity of pupal parasitoids of the stable fly Stomoxys calcitrans and prevalence of entomopathogenic fungi in the stable fly and house fly Musca domestica in Denmark. BioControl 2002; 47(1): 45-60. http://dx.doi.org/10.1023/A:1014434004946.

Urbanek A, Szadziewski R, Stepnowski P, Boros-Majewska J, Gabriel I, Dawgul M, et al. Composition and antimicrobial activity of fatty acids detected in the hygroscopic secretion collected from the secretory setae of larvae of the biting midge Forcipomyia nigra (Diptera: Ceratopogonidae). J Insect Physiol 2012; 58(9): 1265-1276. http://dx.doi.org/10.1016/j. jinsphys.2012.06.014. PMid:22781366.

Watson DW, Geden CJ, Long SJ, Rutz DA. Efficacy of Beauveria bassiana for controlling the house fly and stable fly (Diptera: Muscidae). BioControl 1995; 5(3): 405-411.

Zimmermann G. Review on safety of the entomopathogenic fungi Beauveria bassiana and Beauveria brongniartii. Biocontrol Sci Technol 2007; 17(6): 553-596. http://dx.doi.org/10.1080/09583150701309006. 